RCSS ディスカッションペーパーシリーズ

第 69 号 2008 年 8 月

Discussion Paper Series

No.69 August, 2008

\title{
Herd Behavior by Japanese Banks after Financial Deregulation in the 1980s
}

\author{
Ryuichi Nakagawa and Hirofumi Uchida
}

\section{RCSS}

\author{
文部科学大臣認定 共同利用・共同研究拠点 \\ 関西大学ソシオネットワーク戦略研究機構 \\ 関西大学ソシオネットワーク戦略研究センター \\ (文部科学省私立大学学術フロンティア推進拠点)
}

Research Center of Socionetwork Strategies,

The Research Institute for Socionetwork Strategies,

Kansai University

Suita, Osaka, 564-8680 Japan

URL: http://www.rcss.kansai-u.ac.jp

http://www.socionetwork.jp

e-mail: rcss@jm.kansai-u.ac.jp

tel: 06-6368-1228

fax. 06-6330-3304 


\title{
Herd Behavior by Japanese Banks after Financial Deregulation in the 1980s
}

\author{
Ryuichi Nakagawa and Hirofumi Uchida
}

\section{RCSS}

\author{
文部科学大臣認定 共同利用・共同研究拠点 \\ 関西大学ソシオネットワーク戦略研究機構 \\ 関西大学ソシオネットワーク戦略研究センター \\ (文部科学省私立大学学術フロンティア推進拠点)
}

Research Center of Socionetwork Strategies,

The Research Institute for Socionetwork Strategies,

Kansai University

Suita, Osaka, 564-8680 Japan

URL: http://www.rcss.kansai-u.ac.jp

http://www.socionetwork.jp

e-mail: rcss@jm.kansai-u.ac.jp

tel: 06-6368-1228

fax. 06-6330-3304 


\title{
Herd Behavior by Japanese Banks after Financial Deregulation in the 1980s
}

\author{
Ryuichi Nakagawa $^{1} \quad$ Hirofumi Uchida \\ Faculty of Economics Faculty of Economics \\ Kansai University Wakayama University
}

August 31, 2008

${ }^{1}$ Corresponding author: Faculty of Economics, Kansai University, 3-3-35 Yamate Suita, Osaka 564-0063, Japan. Phone: +81-6-6368-0590. Fax: +81-6-6339-7704. E-mail: ryu-naka@kansai-u.ac.jp. 


\title{
Herd Behavior by Japanese Banks after Financial Deregulation in the 1980s
}

\author{
Ryuichi Nakagawa * \\ Faculty of Economics, Kansai University \\ 3-3-35 Yamate Suita, Osaka 564-0063, Japan. \\ Phone: +81-6-6368-0590. Fax: +81-6-6339-7704. \\ E-mail: ryu-naka@kansai-u.ac.jp. \\ Hirofumi Uchida \\ Faculty of Economics, Wakayama University
}

\begin{abstract}
This paper empirically investigates whether Japanese banks followed herd behavior during the 1980s and 1990s. Using the data of loan portfolios of banks of different types, the paper examines the existence of leader-follower relationships between lending behavior of different types of banks and the inefficiency of the behavior that can cause misallocations of financial resources and macroeconomic fluctuations. The results indicate the existence of herding consistently during the sample period, while the inefficiency of herding is concentrated in the early through mid-1980s, the period immediately after financial deregulation began. In particular, evidence for the inefficient herding is observed in the behavior of banks that made loans to new borrowers, and in the behavior of banks that followed the type of banks that were more informed on lending to new borrowers. On the other hand, inefficient herd behavior is rarely observed in the 1990s.
\end{abstract}

Keywords: herd behavior; Japanese banks; financial deregulation

JEL classification number: G21; E44

${ }^{*}$ Collaborator for research, RCSS, Kansai University 


\section{Introduction}

It has been argued that Japanese banks have engaged in herd behavior (yokonarabi in Japanese), and their behavior has been often criticized as a symbol of the inefficiency of the Japanese financial market. ${ }^{1}$ In the past, the reason for the behavior was simple. Until the late 1970s, Japanese banks were strictly regulated both explicitly and implicitly in all business areas (e.g., loan amounts, interest rates, borrowers, branching, fees). Thus, banks were forced to behave uniformly and to follow the behavior of other banks. ${ }^{2}$

However, even after a series of financial deregulation measures were implemented in the 1980s, collective behavior of Japanese banks that looks like herding has been often observed, and some of them coincided with fluctuations in the Japanese economy. ${ }^{3}$ For example, by the late 1980s, most banks simultaneously decreased the share of their loans to traditional borrowers and increased those to the finance and real estate industries. Ueda[35] concludes that the huge increase in bank lending to those industries was a crucial factor in the formation of the asset-price bubble in the late 1980s. Furthermore, early in the 1990s, banks simultaneously reduced this type of lending. Ogawa and Kitasaka[30] describe this collective contraction as a credit crunch that might have generated the long stagnation in the 1990s. ${ }^{4}$

Despite the fact that herding by Japanese banks has been criticized because it misallocates financial resources and hence causes fluctuations in the economy, few

\footnotetext{
${ }^{1}$ The definition of herding is often different in the literature. Chang, Chaudhuri, and Jayaratne[9] and Buch and Lipponer[7] use the term to describe the collective behavior of agents of any form. On the other hand, Chari and Kehoe[10] define the term as only the collective behavior of agents who ignore their own information and follow the decision made by others. Bikhchandani and Sharma[6] and Chamley[11] similarly define the term to stand for imitation of others. We follow the final definition throughout the paper.

${ }^{2}$ The main reason for the regulation was to discourage competition in the financial markets and to prevent any financial institution from going bankrupt. For overviews of the regulated Japanese financial system during this period, see Hoshi and Kashyap[24, chs 4, 5, and 6], Teranishi[34], and Kitagawa and Kurosawa[27].

${ }^{3}$ Note that some of deregulation measures started in the late 1970s. Hoshi and Kashyap[23][24, chapter 7] survey financial deregulation in three areas: financing, saving, and bank business lines. The financing deregulation with respect to bond markets was implemented earlier than the other areas, because of the huge issuance of government bonds in the late 1970s.

${ }^{4}$ In addition, the Nihon Keizai Shimbun (NIKKEI), Japan's leading economic newspaper, frequently reported herding by Japanese banks during the stagnation period in the 1990s. There was a peak of 146 articles in 1992 when it turned out that the asset-price bubble had burst and the financial system faced serious consequences, while the 1980s had an average of around 20 articles a year.
} 
papers have examined the existence of herding by Japanese banks and its impact on the economy. Most studies, based only on anecdotal evidence, tend to interpret any collective action of Japanese banks as herding that causes inefficiency. However, it is difficult to identify whether the herd behavior has indeed caused the fluctuations in the economy, or the behavior was merely collective behavior as a result of banks uniformly responding to the macroeconomic environment.

The purpose of this paper is to empirically investigate the herd behavior of Japanese banks in the domestic loan market since the 1980s, when a series of financial deregulation measures started in Japan. First, using the data of loan portfolios of Japanese banks, we examine the existence of leader-follower relationships in the lending behavior of different types of banks using causality tests by Jain and Gupta[26] and Barron and Valev[4].

Second, we examine whether or not observed herding of Japanese banks is so inefficient as to cause misallocations of financial resources. Statistical causalities can stem not only from inefficient bank herding, but also from the collective behavior of banks that is generated by changes in economic variables that uniformly affect the loan demand by borrowers and the loan supply by banks. ${ }^{5}$ Furthermore, even if an observed causality is because of bank herding, the herding may not imply inefficiency in terms of misallocation of financial resources. This is because it is possible that follower banks just follow a leader bank that efficiently allocates its loans to promising borrowers. ${ }^{6}$ To investigate whether observed causalities do not stem from such efficient behavior, we control for those macroeconomic factors that can generate the efficient behavior in causality tests and test the existence of leader-follower relationships. ${ }^{7}$

Our empirical results show evidence of leader-follower relationships in loans between different types of Japanese banks in the 1980s. After controlling for the effects of various economic variables, our results again provide evidence for the relation-

\footnotetext{
${ }^{5}$ For example, in the asset price bubble during the late 1980s, most Japanese banks seemed to expect surging land prices to be sustained, and uniformly expanded lending to real estaterelated industries (Ueda[35]). These collective decisions that banks made based on macroeconomic conditions should not be considered herding.

${ }^{6}$ Chamley[11, ch.4] clarifies the conditions under which herd behavior by agents results in the efficient markets equilibrium that is consistent with fundamentals.

${ }^{7}$ Chang, Chaudhuri, and Jayaratne [9] and Buch and Lipponer [7] control clustering in a similar manner to identify inefficient herding. However, we should note that it is difficult to perfectly control for economic conditions to identify inefficient herding. (Alevy, Haigh, and List[2]). Moreover, it is empirically difficult to identify a specific cause of herding among various possible theoretical explanations (Bikhchandani and Sharma[6]).
} 
ships, which suggest inefficient herding by banks. Bank herding is time-specific in the sense that herding is observed in the early- to mid-1980s, which is immediately after the start of financial deregulation. In particular, herding during that period is borrower-specific in the sense that it is observed in loans to new borrowers that became new customers after financial deregulation. In addition, herding is bankspecific in the sense that banks were inclined to follow the lending behavior of banks that were considered to be more informed about the new borrowers.

On balance, our results suggest that financial deregulation in the 1980s created an uncertain environment that induced banks to inefficiently follow herd behavior by inferring creditworthiness of new borrowers from other banks in the early through mid-1980s. This might have contributed to the asset-price bubble in the late 1980s. In contrast, in the 1990s, such inefficient behavior is rarely observed.

Many studies present empirical evidence for bank herding in other countries. Jain and Gupta[26] and Barron and Valev[4] find that herding by US banks occurred in the 1980s, when they increased lending to Latin American countries that were new borrowers for them. Chang, Chaudhuri, and Jayaratne[9] find that US banks in New York City herded in opening branches in new areas in the 1990s, and De Juan[14] finds similar behavior by Spanish banks. Buch and Lipponer[7] find herding by German banks in foreign direct investments.

The contribution of the paper is not only to provide evidence of herding by Japanese banks, but also to present findings that support theoretical predictions in the literature that analyzes herd behavior. ${ }^{8}$ The time-specific feature of herding is consistent with the findings of Barron and Valev[4] and Nelson[29]. They show that herding is long-lived if the real economy is stable across time. Our timespecific feature is consistent with their suggestions, in that herding is observed in the early through mid-1980s when the Japanese economy was relatively stable. The borrower-specific feature supports the prediction by Calvo and Mendoza[12],

\footnotetext{
${ }^{8}$ One of seminal theories of herding behavior of rational agents is offered by the informational cascade model of Banerjee[3] and Bikhchandani, Hirshleifer, and Welch[5], where herding is defined as behavior by an agent that infers unobservable information by referring to the behavior of other agents. Most of the studies mentioned above extend this model under more general conditions. Other theories of herding by rational agents are based on sanctions on deviants (e.g., Akerlof[1] and Hirshleifer and Rasmusen[20]), payoff externalities (Diamond and Dybvig[16] and Devenow and Welch[15]), receipt of correlated private information (Froot, Scharfstein, and Stein[18] and Hirshleifer, Subrahmanyam, and Titman[21]), reputation concerns (Scharfstein and Stein[33]), and similarity of comparative advantage (Falkenstein[17]). For surveys of herd behavior, see Bikhchandani and Sharma[6], Chamley[11], Devenow and Welch[15], Hirshleifer and Teoh[22], and Welch[37].
} 
who suggest that herding tends to happen when the number of investment options increases and agents invest in new assets that they had not invested in previously. The bank-specific feature substantiates the validity of the theory given by Barron and Valev[4]. They indicate that agents with less wealth tend to avoid information gathering and follow agents with more wealth who can easily get information. The bank-specific feature is also consistent with the theory of Menkhoff, Schmidt, and Brozynski[28], who show that less experienced investors tend to exhibit a higher degree of herding.

Furthermore, our finding of herding across different bank types in the early through mid-1980s is complementary to the finding by Uchida and Nakagawa[36]. They find herding within groups of banks of the same type during the period of the asset price bubble of the late 1980s. ${ }^{9}$

This paper also provides two methodological contributions to the empirical literature in this area. First, the paper examines not only the existence of bank herding, but also its inefficiency by controlling for the efficient behavior that is generated by macroeconomic variables (cf., Jain and Gupta[26] and Barron and Valev[4]). Second, the paper also shows time variations in bank herding when we examine different sample periods (cf., Buch and Lipponer[7]). Our analysis therefore provides more robust evidence of inefficient herding behavior.

The remainder of this paper is structured as follows. The next section describes the loan data of Japanese banks and the historical transition of the Japanese loan market. Section 3 conducts causality tests to examine the existence of herd behavior. Section 4 examines the inefficiency of herd behavior. Section 5 proceeds with further analysis and sequential causality tests to analyze time variations in the existence and efficiency of herd behavior. Section 6 concludes the paper.

\section{Loan Data}

This section outlines the characteristics of Japanese banks and data of their loans outstanding that are categorized by borrower. This section also describes the historical transition of borrowers to provide a background for subsequent empirical analysis. Details on the data are in the data appendix.

\footnotetext{
${ }^{9}$ Uchida and Nakagawa[36] use the term "irrational herd behavior," while we use the term "inefficient herd behavior." This is because, in our analysis using macroeconomic data, it is difficult to examine the rationality of individual banks.
} 


\subsection{Bank type}

We focus on four types of Japanese banks: city banks, regional banks, long-term credit banks (hereafter LTC banks), and trust banks. Table 1 shows the loan shares of bank types during 1975-1999.

City banks are the largest banks in Japan. They have branch offices in major cities and operate nationwide, as well as internationally. For decades, loans outstanding of city banks have accounted for more than $40 \%$ of total loans outstanding in Japan.

Regional banks are smaller and operate in the local financial markets where they are located. Although their total loan share is comparable with that of city banks, the average size of regional banks is less than one tenth of that of city banks. ${ }^{10}$

LTC banks had the special aim of long-term financing, while trust banks focused on trust services. Both were often characterized as having been the main providers of long-term funds in postwar Japan until the 1990s. Possibly because of this, they have had a tendency to specialize in loans to the finance and real estate industries, compared with city and regional banks. ${ }^{11}$ This is reflected in Figure 1, which shows the loan shares of those industries in the portfolios of individual bank types.

Later, we focus on leader-follower relationships between the behavior of city banks and that of the other three types. This is because only the scope of business activities of city banks has been very broad and is likely to overlap with that of the other types of banks.

\subsection{Type of borrowers}

Loan data by borrower industry are available for the nine industries: Manufacturing; Construction; Electricity, gas, heat supply and water (hereafter Electricity); Transport and communication (Transport); Wholesale, retail trade, eating and drinking places (Wholesale); Finance and insurance (Finance); Real estate; Services; and Individuals.

Figure 2 and 3 show the changing distribution of bank loans to individual borrower industries. Figure 2 shows loans outstanding to each industry group. Panels (a)-(c) in Figure 3 show the share of loans outstanding to each borrower industry

\footnotetext{
${ }^{10}$ Regional banks are further categorized into regional banks and second-tier regional banks, both with different historical backgrounds. We group them together because the results are similar to when they are analyzed separately.

${ }^{11}$ The definitions of these industries are introduced soon in Section 2.2
} 
to the total loans outstanding. Borrower industries are classified into three groups based on the distinct pattern of transitions. The first group is traditional industries (manufacturing and wholesale), which were the dominant borrowers until the late 1970s. Their outstanding loans have become stable during the 1980s, and their loan shares decreased from about 30\% to 15\%. The second group is emerging industries (finance, real estate, services, and individuals) that gradually took over as the major borrowers from the mid-1980s in terms of loans outstanding as well as loan share. The third group is status quo industries (construction, electricity, and transport), which have marginal and stable shares during the period.

These patterns reflect a variety of institutional changes in the Japanese financial market. Traditional industries were composed of large corporations, and had been borrowing huge sums since World War II. However, financial deregulation from the 1980s enabled them to access other sources of financing. ${ }^{12}$ As a result, their total bank borrowing became largely flat in the mid-1980s. This shift away from direct reliance on banks is known as financial disintermediation.

Deregulation helped boost the loans outstanding and loan shares of emerging industries beginning in the early 1980s. Banks, which had lost their dominance over lending to traditional industries, had to look for new borrowers. They thus promoted loans to emerging industries, as their loan demand also expanded in this booming period. The asset-price bubble of the mid- to late 1980s also contributed to the influx of funds into the emerging industries. This is because the surge in land values made it easier for banks to lend to new borrowers and others using land as collateral.

Compared with the 1980s, the 1990s shows stability in the loan shares. That is, little change is observed after the implosion of the asset-price bubble in the early 1990s. In this sense, the structural and strategic consequences of deregulation in the 1980s largely played out during the 1980s, although deregulation continued during the 1990s. Together with the fact that the 1990s is a period of stagnation and banking crises, we expect the behavior of Japanese banks in the 1990s to be different from the 1980s.

Based on these observations, bank loans seem to have been affected by several

\footnotetext{
${ }^{12}$ The deregulation includes such institutional reforms as the Foreign Exchange and Trade Control Act (December 1980) and enforcement of the New Banking Act (April 1982). The Japan-US Yen Dollar Committee report (June 1984) was also a factor. See Hoshi and Kashyap[23][24, ch 7], Ramseyer[32] and Campbell and Hamao[13] for more details.
} 
factors, such as structural changes across time, type of borrower, and type of bank. We categorize our data according to the above predictions, and try to detect features of herding by Japanese banks. However, we do not analyze the status quo industries because the loan shares to these industries were marginal and stable.

\section{Existence of Herd Behavior}

In this section, we empirically examine whether leader-follower relationships existed between the behavior of city banks and that of the other types of banks in the Japanese loan market. First of all, following the standard methodology utilized in the literature (e.g., Jain and Gupta[26], Barron and Valev[4]), we focus on specific sample periods and test statistical causalities between loan variables of different bank types. In Section 5, we introduce a more elaborate methodology.

\subsection{Methodology}

The present methodology is to estimate two-variate vector autoregressive (VAR) models of the loan data of city banks and those of one of the other bank types. Then we test for causalities between those loan variables.

We focus on four sample periods based on the historical background outlined in Section 2.2 and because of data availability: 1975:1-1984:4, 1980:1-1989:4, 1985:11994:4, and 1990:1-1999:4. The data observations are quarterly. The four sample periods serially overlap with each other by five years to identify time variations of herd behavior under sufficient degrees of freedom. In this paper, although we do not discuss bank herding in the regulation period until the late 1970s, we also analyze the 1975-1984 sample period to capture changes in bank herding from the regulation period to the deregulation period. ${ }^{13}$

As a loan variable that represents the decisions of each type of bank in lending to each industry group, we use the ratio of the loans outstanding of that bank type for the industry group over the total loans outstanding of that bank type. The size of loans outstanding is thus normalized, allowing us to examine whether banks

\footnotetext{
${ }^{13}$ Another reason for the focus on the period after the 1980s is because window guidance by the Bank of Japan became less important thereafter. Until 1981, the Bank set a plan of total loans outstanding for each domestic bank every quarter; hence, any increases in loans were entirely controlled as planned. In 1982, guidance was reformed to take the form of a voluntary submission of planned lending by individual banks, and was lifted completely in July 1991.
} 
adjusted their portfolio composition by herding. ${ }^{14}$

\section{$3.2 \quad$ Results}

Table 2 shows the results of the causality tests between loan portfolios of city banks and those of the other types of banks. Positive causalities are interpreted as evidence of herd behavior. ${ }^{15}$ We find several features in the observed causalities. First, a time-specific feature is observed in the sense that causalities are seens most frequently in the 1980s, when financial deregulation started. Second, a bank-specific feature is observed because causalities are most frequently from LTC and trust banks to city banks during 1980-89 and 1985-94, and from city banks to regional banks during 1980-89.

These results suggest that Japanese banks often followed herd behavior after the financial deregulation that started in the 1980s. In particular, deregulation might have stimulated bank herding, as causalities are observed most frequently in the 1980s and disappeared by the 1990s. As is explained in Section 2.2, financial disintermediation forced most banks to adjust to the new environment created by deregulation. As a result, each type of bank might have followed more informed types of banks. For city banks, LTC and trust banks might have a comparative advantage in loans to emerging industries (Figure 1). For regional banks, city banks were deemed likely to have a greater potential to adjust to the new financial environment. 16

On the other hand, causalities disappear by the 1990s, the period of the long stagnation and financial crises in Japan. This finding does not support the anecdotal

\footnotetext{
${ }^{14}$ We do not use the level data of loans outstanding, which are more likely to uniformly respond to macroeconomic trends than are the ratio data. To make sure, we did the same test by using the level data, but loans of different banks are often highly correlated and showed causalities in all sample periods. Other favorable data are, for example, a series on New Loans for Equipment Funds by Industry published by the Bank of Japan, which seems to be less affected by macroeconomic trends. However, the data are not categorized by bank type.

${ }^{15}$ There are several negative estimates of coefficients. Buch and Lipponer[7] interpret the negative coefficient as the effect of competition between loans of different types of banks that overwhelms the herding effect between them. This is an interesting topic for future research.

${ }^{16}$ This phenomenon may be considered a version of the Cowbell effect, which is noted by Higano[19]. Higano points out that there might have been an inducement effect in loans made by the Japan Development Bank (JDB, presently the Development Bank of Japan, a government financial institution). He claims that loans made by JDB signaled that the government was happy with the loans, and that the government therefore implicitly guaranteed the loans. Packer[31] argues that the LTC banks played a similar role to JDB's, providing long-term funds to borrowers who were important in Japan's postwar development.
} 
argument that Japanese banks followed herd behavior during that period.

In contrast to our prediction, the borrower-specific feature of herding - different results for different borrowers - is not clearly observed. Causalities are observed not only in loans to emerging industries, but also in loans to traditional industries. We check the robustness of this result later.

\section{Inefficient Herd Behavior}

Next we test whether the observed causalities reflect inefficient herd behavior. If causalities are found even after controlling for macroeconomic factors, it suggests that bank herding is inefficient in the sense that herding induces misallocations of bank loans that are not consistent with macroeconomic conditions.

\subsection{Methodology}

We introduce into the causality tests three types of macroeconomic variables that may uniformly affect loan variables of all bank types.

First, the ratio of nominal GDP by industry group to aggregate nominal GDP and the ratio of the stock price index by industry group to the TOPIX (a broad market stock index) are used to control for changes in profitability of borrowers and the relative size of loan demand by each industry group.

Second, deregulation beginning in the 1980s accelerated disintermediation by traditional industries. Then the ratio of total private bonds outstanding to aggregate nominal GDP is used to control for the structural shift in loan demand by traditional industries.

Third, the surge in land prices in the 1980s seems to have stimulated loan demand by emerging industries because land could be used as collateral, especially in lending to new borrowers. Then the ratio of a nationwide land price index to aggregate nominal GDP is used to control for changes in loan demand by emerging industries.

One and two period lags of these control variables are introduced, not only to effectively control for efficient herding, but also to mitigate the endogenous bias problem. ${ }^{17}$

\footnotetext{
${ }^{17}$ We also conducted an analysis in which estimated expected values of macroeconomic variables were used as control variables instead of their realized values, because expected variables could be better proxies for the changes in loan demand than the realized ones were. However, it turned
} 
Note that we do not introduce a variable that equally affects loan supply or demand of all borrowers, because such a variable is less likely to affect a bank's portfolio composition. For example, the level of aggregate GDP, TOPIX, or call rates does not change the loan ratio of specific borrowers. When those variables were introduced, they were mostly insignificant in VAR estimations. ${ }^{18}$

\subsection{Results}

Table 3 shows the results of inefficient herd behavior between city banks and the other types. Similar to Table 2, we can observe significant causalities after deregulation, although most of the causal relationships become less significant. We observe a slight time-specific herding in that causalities are observed most frequently during 1980-89, but it is not as significant as that in Table 2. The bank-specific feature is also obscure, although causalities from city to regional banks are still observed during 1980-89.

In summary, Table 3 does not provide strong evidence that supports the inefficiency of herd behavior by Japanese banks in any period after financial deregulation. Nor is the borrower-specific feature clearly observed after the 1980s. Significant causalities are sparse in both industry groups, except for during 1975-84. At this point, we temporarily conclude that there might have been bank herd behavior after deregulation, but that the behavior might not have caused inefficiency in the loan market. These conclusions are in contrast to the predictions of anecdotal arguments.

\section{Further Analysis: Sequential Causality Test}

To check the robustness of the result in the previous section, we move on to a more detailed analysis. A possible reason why we could not find evidence for inefficient

out that the results were similar. In addition, we conducted the same tests in which the lag of the VAR was fixed at four. However, the results were unchanged.

${ }^{18}$ Furthermore, the amount of non-performing loans (NPLs) in the 1990s might have had unequal effects among the loan demand of different borrowers. However, we do not introduce it because such data are not consistently available for our sample period. Another reason is that it is unclear whether the amount of NPLs to a specific industry had a consistent effect on new loans to that industry. On the one hand, a huge amount of NPLs might discourage new loans; on the other hand, the NPLs might force banks to increase loans to non-performing borrowers to prevent the remaining loans from being declared non-performing. Hoshi and Kashyap[25] discuss this last effect and survey the related literature. 
herding is that bank behavior might have been changing gradually over time, preventing inefficient herding from being detected just by focusing on a few specific sample periods. We thus run the same test over all possible sample periods and investigate time variations in inefficient herding by Japanese banks.

For this purpose, we conduct the sequential causality test. First, we select the earliest ten-year sample period from the whole sample period and examine a causality as in the previous sections. Next, we shift the sample period by one quarter and examine the same causality. We repeat this procedure sequentially until the end of the selected sample period reaches the end of the whole period. The advantage of this test is that we can detect more accurately time variations in a causality relationship.

\subsection{Existence of Herd Behavior}

Figure 4 shows the results for the existence of herd behavior between city banks and the other types of banks. In each panel, the solid line represents the estimated sum of coefficients of the loan variable of the type of banks that is the explanatory variable in the VAR. The shadowed area indicates that causalities are significant.

The figure confirms features of herding similar to those observed in Table 2 . Regarding the time-specific feature, most causalities appear persistently in the 1980s, immediately after deregulation began, and almost disappears by the 1990s. The bank-specific feature is found more clearly in the 1980s in both industry groups - city banks follow LTC and trust banks, and regional banks follow city banks - implying that banks are inclined to follow more informed banks. Again, the borrower-specific feature is not distinctly found among observed causalities in loans to either industry group.

Interestingly, causalities are found in the 1990s from city to LTC banks in the emerging industries. This might indicate not only the possibility of herding in the 1990s, but also the expansion of forbearance lending by both types to unprofitable borrowers, mainly real estate firms. Caballero, Hoshi, and Kashyap[8] argue that major Japanese banks have conducted so-called zombie lending in the 1990s after the collapse of the asset-price bubble. To verify this claim, however, additional researches are needed.

In terms of the existence of herd behavior, therefore, we confirm more clearly the features that are found in Section 3.2. We can thus conclude that financial 
deregulation might have stimulated herd behavior across different types of Japanese banks in the 1980s. In contrast, our results seldom support the anecdotal argument that Japanese banks followed herd behavior in the 1990s.

\subsection{Inefficient Herd Behavior}

Figure 5 shows results indicating the inefficiency of herd behavior. In contrast to the results in Table 3, we find several causal relationships that may clearly reflect the influence of deregulation and features of herding. First, causalities exist in the early through mid-1980s, and mostly disappears in the late 1980s. On the other hand, robust causalities are rarely found in the 1990s, except for LTC banks following city banks in lending to emerging industries. Second, bank-specific causalities are observed more frequently than in Figure 4: from LTC and trust banks to city banks in the early 1980s, and from city to regional banks in the mid-1980s.

Interestingly, the borrower-specific feature is now clearly observed in that causalities are stronger in loans to emerging industries after deregulation. In previous sections, we did not find any difference between the behavior of banks in lending to traditional borrowers and the behavior in lending to emerging borrowers. Here, most of the causalities in traditional industries observed in Figure 4 are eliminated by control variables, and causalities in emerging industries remain significant.

Our results generally indicate that Japanese banks inefficiently followed herd behavior immediately after the beginning of financial deregulation. In that period, inefficient herding is observed, particularly in lending to emerging industries, possibly because of the lack of information about those new borrowers. The inefficient behavior took the form of city banks following more informed LTC and trust banks in the early 1980s, and regional banks following more informed city banks in the mid-1980s. 19

Considering the rapid growth of loans to emerging industries in the 1980s, inefficient herd behavior caused by deregulation might have contributed to subsequent

\footnotetext{
${ }^{19}$ This time lag between herding of regional banks and that of city banks is consistent with the literature about delayed herding. Chari and Kehoe[10] establish a cascade model in which investors delay investment to gain information and start herding when waiting becomes costly because of discounting. Furthermore, Barron and Valev[4] establish a model in which smaller banks endowed with insufficient wealth are more likely to not gather costly information on investment prospects, but rather rely on the behavior of more informed banks with some delay to infer information about international investment prospects. We assume that regional banks needed more time to learn the new environment than city banks did.
} 
economic fluctuations through emerging loans by less informed banks. This historical transition is very similar to the findings of empirical studies about herd behavior by US banks. Jain and Gupta[26] and Barron and Valev[4] find that small US banks relied on the lending behavior of major US banks in lending to unfamiliar developing countries in the late 1970s and early 1980s.

\section{Conclusion}

This paper has examined empirically whether Japanese banks followed herd behavior after financial deregulation started in the early 1980s, and whether their herding hadbrought about inefficient outcomes that could have led to subsequent macroeconomic fluctuations.

Herd behavior of Japanese banks has been considered a symbol of the inefficiency of the Japanese financial market. Even though the behavior seemed to have disappeared following deregulation, there has been much anecdotal evidence for herd behavior by banks, which has been blamed for economic problems.

Our empirical results suggest that Japanese banks frequently followed herd behavior after financial deregulation, and that the inefficiency of their herding was the most crucial in the early through mid-1980s, immediately after the beginning of deregulation. In that period, the inefficient behavior seems to have been significant in lending to new borrowers in the deregulation period. In addition, banks seem to have followed those banks that were more informed in lending to new borrowers. These results are consistent with theoretical predictions in the literature and suggest the possibility that inefficient herding might have contributed to the formation of the asset-price bubble in the late 1980s. On the other hand, the results do not support anecdotal evidence of inefficient herd behavior in the 1990s.

There are two important issues that were not considered in this paper. First, we do not empirically investigate whether and how inefficient herding contributed to the formation of the asset-price bubble in the late 1980s and the accumulation of non-performing loans in the 1990s. Second, we focused solely on the question of whether observed herd behavior was efficient, while we did not investigate the theoretical causes of the observed herding. These issues are to be investigated in a separate study. 


\section{Data Appendix}

All the data used in this paper are available from Nikkei NEEDS Macroeconomic Data File. The original sources are shown below.

\section{Loans Outstanding}

Loan data are available from "Loans and Discounts Outstanding by Sector" in the Financial and Economic Statistics Monthly of the Bank of Japan. The data include the amount of loans supplied to different industries by type of bank. Data for trust bank lending to the finance and insurance industries are available only from the first quarter of 1977. No data for LTC and trust banks are available from the fourth quarter of 2000.

The types of banks and their loans outstanding are defined as follows. First, regional and second-tier regional banks are combined as regional banks. Second, the loans outstanding of trust banks are defined as Banking Accounts of Trust Banks + Trust Accounts of Domestically Licensed Banks. The latter includes loans outstanding in the trust accounts of all Domestically Licensed Banks - that is, trust banks and the other types of banks - and they cannot be separated between trust banks and other banks. However, the amount held by non-trust banks is negligible compared with the amount held by trust banks.

\section{GDP}

GDP data are available from the Annual Report on National Accounts prepared by the Cabinet Office. We utilize nominal data from 68SNA (original series, at market prices in calendar 1990) for the years until 1979, and from 93SNA (original series, at market prices in calendar 1995) for the years from 1980. The data include aggregate nominal GDP and nominal GDP by industry.

Although the industry classification is almost the same as that of the loan data, there are no nominal GDP data for Individuals. Real estate GDP is used as a proxy for the GDP of Individuals. Since nominal GDP by industry is available only on an annual basis, we construct a quarterly data series by interpolating the original data.

In the causality test, nominal GDP by industry group is calculated as the sum of the nominal GDPs of the industries included in the relevant industry group. For 
example, the nominal GDP of the traditional industries is calculated as the sum of the nominal GDPs of Manufacturing and Wholesale industries.

\section{Stock Price Index}

Stock price data are available from the Monthly Statistics Report from the Tokyo Stock Exchange. The data include TOPIX and TOPIX Stock Price Index by Industry.

The industry classification is slightly different from that of the loan data. Therefore, the most closely related stock price index by industry is chosen as a proxy for the index for the relevant industry group or the industry itself. In the simple and sequential causality tests, the Electric Appliances Index is applied for traditional industries, and the Real Estate Index is used for emerging industries.

Since Wholesale and Bank Indexes are not available until 1982, the analysis that uses data prior to 1982 uses the Machinery and Real Estate Indexes for Wholesale and Finance, respectively. The Machinery Index is chosen because it is the most highly correlated with the Wholesale Index of all indexes regarding traditional industries during 1983-1999. The Real Estate Index is the most highly correlated with the Bank Index of all indexes regarding emerging industries during 1983-1999.

\section{Other Data}

Bond data are available from the Annual Report of the Japan Securities Dealers Association. The data include Total Private Bonds Outstanding, and are used to establish the proxy for disintermediation.

Land price data are available from the Japan Real Estate Institute. The data include the Nationwide Urban Land Price Index, which is used to establish the proxy for the collateral value of loans to emerging industries.

\section{Acknowledgements}

This paper was presented at the Center on Japanese Economy and Business (CJEB), Columbia University, and the 2007 Australasian Meeting of the Econometric Society. The authors are grateful to Necmi Avkiran, Ken-ya Fujiwara, Takashi Hatakeda, Keiichi Hori, Fumiharu Mieno, Hugh Patrick, Daniel Smith, Yosuke Takeda, and David Weinstein for helpful comments. However, the authors are solely responsible 
for any remaining errors. Most of the research was advanced during the first author's sabbatical leave at the CJEB. He thanks Hugh Patrick and David Weinstein for their great hospitality and encouragement for the publication of this essay as a CJEB Working Paper. The first author also thanks the Financial System Workshop, and the second author thanks Japan's Ministry of Education, Science, Sports

and Culture for a Grant-in-Aid for Scientific Research (C) (No.15530214, 2003), Wakayama University Research Fund, and the Research Center of Socionetwork Strategies at Kansai University for their financial support.

\section{References}

[1] G.A. Akerlof. A Theory of Social Custom, of Which Unemployment May be One Consequence. Quarterly Journal of Economics, vol.94, no.4, pp.749-775, 1980.

[2] J.E. Alevy, M.S. Haigh, and J.A. List. Information Cascades: Evidence from a Field Experiment with Financial Market Professionals. Journal of Finance, vol.62, no.1, pp.151-180, 2007.

[3] A. Banerjee. A Simple Model of Herd Behavior. Quarterly Journal of Economics, vol.107, no.3, pp.797-817, 1992.

[4] J.M. Barron and N.T. Valev. International Lending by U.S. Banks. Journal of Money, Credit, and Banking, vol.32, no.3, pp.357-381, 2000.

[5] S. Bikhchandani, D. Hirshleifer, and I. Welch. A Theory of Fads, Fashion, Custom, and Cultural Change as Informational Cascades. Journal of Political Economy, vol.100, no.5, pp.992-1026, 1992.

[6] S. Bikhchandani and S. Sharma. Herd Behavior in Financial Markets: A Review. IMF Working Paper, no.0048, 2000.

[7] C.M. Buch and A. Lipponer. Clustering or Competition? The Foreign Investment Behaviour of German Banks. International Journal of Central Banking, vol.2, no.2, pp.135-168, 2006.

[8] R.J. Caballero, T. Hoshi, and A.K. Kashyap. Zombie Lending and Depressed Restructuring in Japan. NBER Working Paper, no.12129, 2006. 
[9] A. Chang, S. Chaudhuri, and J. Jayaratne. Rational Herding and the Spatial Clustering of Bank Branches: An Empirical Analysis. Federal Reserve Bank of New York Research Paper, no.9724, 1997.

[10] V.V. Chari and P.J. Kehoe. Financial Crises as Herds: Overturning the Critiques. Journal of Economic Theory, vol.119, no.1, pp.128-150, 2004.

[11] C.P. Chamley. Rational Herds: Economic Models of Social Learning, Cambridge University Press, 2004.

[12] G.A. Calvo and E.G. Mendoza. Mexico's Balance-of-payments Crisis: A Chronicle of a Death Foretold Herding. Journal of International Economics, vol.41, no.3, pp.235-264, 1996.

[13] J.Y. Campbell and Y. Hamao. Changing Patterns of Corporate Financing and the Main Bank System in Japan. In M. Aoki and H. Patrick eds, The Japanese Main Bank System, Oxford University Press, 1994.

[14] R. de Juan. The Independent Submarkets Model: An Application to the Spanish Retail Banking Market. International Journal of Industrial Organization, vol.21, no.10, pp.1461-1487, 2003.

[15] A. Devenow and I. Welch. Rational Herding in Financial Economics. European Economic Review, vol.40, no.3-5, pp.603-615, 1996.

[16] D.W. Diamond and P. Dybvig. Bank Runs, Deposit Insurance, and Liquidity. Journal of Political Economy, vol.91, no.3, pp.401-419, 1983.

[17] E.G. Falkenstein. Preferences for Stock Characteristics as Revealed by Mutual Fund Portfolio Holdings. Journal of Finance, vol.51, no.1, pp.111-135, 1996.

[18] K. Froot, D.S. Scharfstein, and J.C. Stein. Herd on the Street: Informational Inefficiencies in a Market with Short-term Speculation. Journal of Finance, vol.47, no.4, pp.1461-1484, 1992.

[19] M. Higano. Kinyu Kikan no Shinsa Noryoku (Monitoring Ability of Financial Institutions) (in Japanese), University of Tokyo Press, 1986. 
[20] D. Hirsleifer and E. Rasmusen. Cooperation in a Repeated Prisoners' Dilemma with Ostracism. Journal of Economic Behavior and Organization, vol.12, no.1, pp.87-106, 1989.

[21] D. Hirshleifer, A. Subrahmanyam, and S. Titman. Security Analysis and Trading Patterns when Some Investors Receive Information before Others. Journal of Finance, vol.49, no.5, pp.1665-1698, 1994.

[22] D. Hirshleifer and S.H. Teoh. Herd Behavior and Cascading in Capital Markets: A Review and Synthesis. European Financial Management, vol.9, no.1, pp.2366, 2003.

[23] T. Hoshi and A. Kashyap. The Japanese Banking Crisis: Where Did it Come From and How Will it End? NBER Macroeconomic Annual 1999, 2000.

[24] T. Hoshi and A. Kashyap. Corporate Financing and Governance in Japan, MIT Press, 2001.

[25] T. Hoshi and A. Kashyap. Solutions to Japan's Banking Problems: What Might Work and What Definitely Will Fail. In T. Ito, H. Patrick, and D. Weinstein eds, Reviving Japan's Economy: Problems and Prescriptions, MIT Press, 2005.

[26] A.K. Jain and S. Gupta. Some Evidence on 'Herding' Behavior of U.S. Banks. Journal of Money, Credit and Banking, vol.19, no.1, pp.78-89, 1987.

[27] H. Kitagawa and Y. Kurosawa. Japan: Development and Structural Change of the Banking System. In H.T. Patrick and Y.C. Park eds, The Financial Development of Japan, Korea, and Taiwan, Oxford University Press, pp.81128, 1994.

[28] L. Menkhoff, U. Schmidt, and T. Brozynski. The Impact of Experience on Risk Taking, Overconfidence, and Herding of Fund Managers: Complementary Survey Evidence. European Economic Review, vol.50, no.7, pp.1753-1766, 2006.

[29] L. Nelson, Persistence and Reversal in Herd Behavior: Theory and Application to the Decision to Go Public. Review of Financial Studies, vol.15, no.1, pp.6595, 2002. 
[30] K. Ogawa and S. Kitasaka. Bank Lending in Japan: Its Determinants and Macroeconomic Implications. In T. Hoshi and H. Patrick eds, Crisis and Change in the Japanese Financial System, Kluwer Academic Publishers, 2000.

[31] F. Packer. The Role of Long-term Credit Banks within the Main Bank System. In M. Aoki and H. Patrick eds, The Japanese Main Bank System, Oxford University Press, 1994.

[32] J.M. Ramseyer. Explicit Reasons for Implicit Contracts: The Legal Logic to the Japanese Main Bank System. In M. Aoki and H. Patrick eds, The Japanese Main Bank System, Oxford University Press, 1994.

[33] D.S. Scharfstein and J.C. Stein. Herd Behavior and Investment. American Economic Review, vol.80, no.3, pp.465-479, 1990.

[34] J. Teranishi. Japan: Development and Structural Change of the Financial System. In H.T. Patrick and Y.C. Park eds, The Financial Development of Japan, Korea, and Taiwan, Oxford University Press, pp.27-80, 1994.

[35] K. Ueda. Causes of Japan's Banking Problems in the 1990s. In T. Hoshi and H. Patrick eds, Crisis and Change in the Japanese Financial System, Kluwer Academic Publishers, 2000.

[36] H. Uchida and R. Nakagawa. Herd Behavior in the Japanese Loan Market: Evidence from Bank Panel Data. Journal of Financial Intermediation, vol.16, no.4, pp.555-583, 2007.

[37] I. Welch. Herding among Security Analysts. Journal of Financial Economics, vol.58, no.3, pp.369-396, 2000. 
Table 1 Loan Shares of Different Types of Japanese Banks

\begin{tabular}{|c|c|c|c|c|c|}
\hline \multirow{2}{*}{ Year } & \multirow{2}{*}{$\begin{array}{c}\text { Total loans } \\
\text { outstanding (a) } \\
\text { (billion yen) }\end{array}$} & \multicolumn{4}{|c|}{ Loan share of each bank type (\%) } \\
\hline & & City & Regional & LTC & Trust \\
\hline 1975 & 112,502 & 42.0 & 34.7 & 9.8 & 13.5 \\
\hline 1976 & 125,303 & 41.6 & 35.0 & 9.8 & 13.6 \\
\hline 1977 & 137,120 & 41.2 & 35.5 & 9.8 & 13.5 \\
\hline 1978 & 151,197 & 40.9 & 36.4 & 9.6 & 13.1 \\
\hline 1979 & 161,598 & 40.6 & 36.8 & 9.6 & 13.0 \\
\hline 1980 & 173,260 & 40.5 & 37.1 & 9.5 & 12.9 \\
\hline 1981 & 190,276 & 40.5 & 37.2 & 9.6 & 12.7 \\
\hline 1982 & 208,917 & 40.5 & 37.2 & 9.7 & 12.6 \\
\hline 1983 & 228,694 & 40.7 & 36.9 & 9.7 & 12.7 \\
\hline 1984 & 250,826 & 41.0 & 36.2 & 9.8 & 13.0 \\
\hline 1985 & 275,141 & 41.5 & 35.2 & 10.2 & 13.1 \\
\hline 1986 & 298,130 & 42.4 & 33.6 & 10.0 & 14.0 \\
\hline 1987 & 326,613 & 42.8 & 33.4 & 10.3 & 13.4 \\
\hline 1988 & 350,105 & 42.8 & 33.9 & 10.3 & 13.0 \\
\hline 1989 & 384,625 & 42.6 & 34.2 & 10.4 & 12.8 \\
\hline 1990 & 408,791 & 42.4 & 34.3 & 10.6 & 12.7 \\
\hline 1991 & 421,083 & 42.0 & 34.5 & 10.7 & 12.8 \\
\hline 1992 & 427,972 & 41.8 & 34.7 & 10.5 & 13.0 \\
\hline 1993 & 511,018 & 43.9 & 35.3 & 9.3 & 11.5 \\
\hline 1994 & 508,850 & 43.5 & 36.1 & 9.2 & 11.3 \\
\hline 1995 & 512,747 & 42.5 & 36.9 & 9.3 & 11.3 \\
\hline 1996 & 512,060 & 42.4 & 37.3 & 9.2 & 11.1 \\
\hline 1997 & 513,748 & 43.0 & 37.6 & 8.8 & 10.6 \\
\hline 1998 & 502,902 & 43.5 & 38.6 & 8.2 & 9.7 \\
\hline 1999 & 482,246 & 44.5 & 39.0 & 7.0 & 9.5 \\
\hline
\end{tabular}

Source: Nikkei NEEDS Macroeconomic Data File. 
Table 2 Causality Tests regarding Existence of Herd Behavior

(a) $1975: 1--1984: 4$

\begin{tabular}{|c|c|c|c|c|c|c|}
\hline & \multicolumn{3}{|c|}{ Traditional } & \multicolumn{3}{|c|}{ Emerging } \\
\hline & Lag & $=>$ City & City $=>$ & Lag & $=>$ City & City $=>$ \\
\hline Regional & 1 & $0.154^{* * *}$ & -0.096 & 4 & -0.080 & -0.095 \\
\hline LTC & 2 & $0.138^{* *}$ & 0.078 & 2 & 0.008 & -0.022 \\
\hline Trust & 4 & $0.312^{* * *}$ & 0.056 & \multicolumn{3}{|c|}{ N.A. } \\
\hline
\end{tabular}

(b) 1980:1 -- 1989:4

\begin{tabular}{|c|c|c|c|c|c|c|}
\hline & \multicolumn{3}{|c|}{ Traditional } & \multicolumn{3}{|c|}{ Emerging } \\
\hline & Lag & $=>$ City & City => & Lag & $=>$ City & City $=>$ \\
\hline Regional & 1 & -0.365 & $0.402 * * *$ & 1 & -0.612 & $0.366^{* * *}$ \\
\hline LTC & 1 & $0.067 * * *$ & -0.066 & 1 & $0.085^{* * *}$ & -0.052 \\
\hline Trust & 1 & $0.094^{* * *}$ & -0.104 & 3 & $0.127 * * *$ & -0.081 \\
\hline
\end{tabular}

(c) $1985: 1$-- 1994:4

\begin{tabular}{|c|c|c|c|c|c|c|}
\hline & \multicolumn{3}{|c|}{ Traditional } & \multicolumn{3}{|c|}{ Emerging } \\
\hline & Lag & $=>$ City & City $=>$ & Lag & $=>$ City & City $=>$ \\
\hline Regional & 1 & 0.228 & -0.004 & 1 & 0.030 & 0.028 \\
\hline LTC & 1 & $0.353^{* * *}$ & -0.044 & 3 & $0.336^{* *}$ & 0.171 \\
\hline Trust & 2 & $0.123^{* *}$ & -0.049 & 1 & $0.249 * * *$ & -0.199 \\
\hline
\end{tabular}

(d) 1990:1 -- 1999:4

\begin{tabular}{|c|c|c|c|c|c|c|}
\hline & \multicolumn{3}{|c|}{ Traditional } & \multicolumn{3}{|c|}{ Emerging } \\
\hline & Lag & $=>$ City & City $=>$ & Lag & $=>$ City & City $=>$ \\
\hline Regional & 1 & -0.065 & -0.027 & 1 & -0.012 & 0.018 \\
\hline LTC & 3 & -0.162 & 0.068 & 1 & -0.096 & -0.246 \\
\hline Trust & 1 & 0.059 & -0.056 & 1 & 0.070 & -0.116 \\
\hline
\end{tabular}

Note: This table shows the results regarding causalities between the loan portfolio of city banks and those of the other types of banks in individual industry groups. The rows of each panel show the types of banks whose relationships with city banks are being investigated. Two columns show the industry groups as borrowers. " Lag " represents the optimal lag of a VAR, which is determined based on SBIC. " $=>$ City " represents a causality from the relevant type of banks to city banks. " City $=>$ " is the reverse causality. Each value is an estimated sum of the coefficients of the loan portfolio of the type of banks that is an explanatory variable in the VAR. The superscript $* * *$ means that the sum of coefficients is positive and significant at $1 \%$ level in an F-test; ** at 5\%; * at 10\%. Results regarding trust banks for 1975-84 are not available because of a lack of data. Our VAR includes a constant term, seasonal dummies, and a dummy variable for the change in the definition of the data in the second quarter of 1993. 
Table 3 Causality Tests regarding Inefficient Herd Behavior

(a) $1975: 1$-- 1984:4

\begin{tabular}{|c|c|c|c|c|c|c|}
\hline & \multicolumn{3}{|c|}{ Traditional } & \multicolumn{3}{|c|}{ Emerging } \\
\hline & Lag & $=>$ City & City $=>$ & Lag & $=>$ City & City $=>$ \\
\hline Regional & 1 & $0.192 * *$ & -0.142 & 2 & -0.106 & -0.013 \\
\hline LTC & 2 & $0.147^{*}$ & 0.020 & 1 & $0.197^{* * *}$ & -0.511 \\
\hline Trust & 2 & $0.222 * *$ & -0.014 & \multicolumn{3}{|c|}{ N.A. } \\
\hline
\end{tabular}

(b) 1980:1 -- 1989:4

\begin{tabular}{|c|c|c|c|c|c|c|}
\hline & \multicolumn{3}{|c|}{ Traditional } & \multicolumn{3}{|c|}{ Emerging } \\
\hline & Lag & $=>$ City & City $=>$ & Lag & $=>$ City & City $=>$ \\
\hline Regional & 1 & 0.185 & $0.292^{* *}$ & 1 & 0.214 & $0.46^{* * *}$ \\
\hline LTC & 1 & 0.075 & -0.074 & 1 & 0.079 & -0.165 \\
\hline Trust & 1 & $0.108^{*}$ & -0.215 & 1 & $0.233 *$ & -0.340 \\
\hline
\end{tabular}

(c) $1985: 1-1994: 4$

\begin{tabular}{|c|c|c|c|c|c|c|}
\hline & \multicolumn{3}{|c|}{ Traditional } & \multicolumn{3}{|c|}{ Emerging } \\
\hline & Lag & $=>$ City & City $=>$ & Lag & $=>$ City & City $=>$ \\
\hline Regional & 1 & 0.105 & 0.080 & 2 & 0.103 & -0.017 \\
\hline LTC & 1 & 0.168 & 0.002 & 2 & $0.318^{* *}$ & $0.45^{* *}$ \\
\hline Trust & 2 & 0.004 & -0.083 & 1 & 0.160 & -0.098 \\
\hline
\end{tabular}

(d) 1990:1 -- 1999:4

\begin{tabular}{|c|c|c|c|c|c|c|}
\hline & \multicolumn{3}{|c|}{ Traditional } & \multicolumn{3}{|c|}{ Emerging } \\
\hline & Lag & $=>$ City & City $=>$ & Lag & $=>$ City & City $=>$ \\
\hline Regional & 1 & $0.534^{*}$ & 0.063 & 3 & -0.090 & -0.346 \\
\hline LTC & 3 & -0.356 & 0.045 & 1 & -0.121 & 0.131 \\
\hline Trust & 2 & 0.022 & 0.069 & 1 & 0.037 & -0.197 \\
\hline
\end{tabular}

Note: This table shows the results regarding causalities between loan ratios of city banks and those of the other types of banks in individual industry groups, with one and two lagged macroeconomic variables. Other detail is seen in Table 2. 
Figure 1 Loan Shares of Finance and Real estate Industries in Portfolios of Bank Types

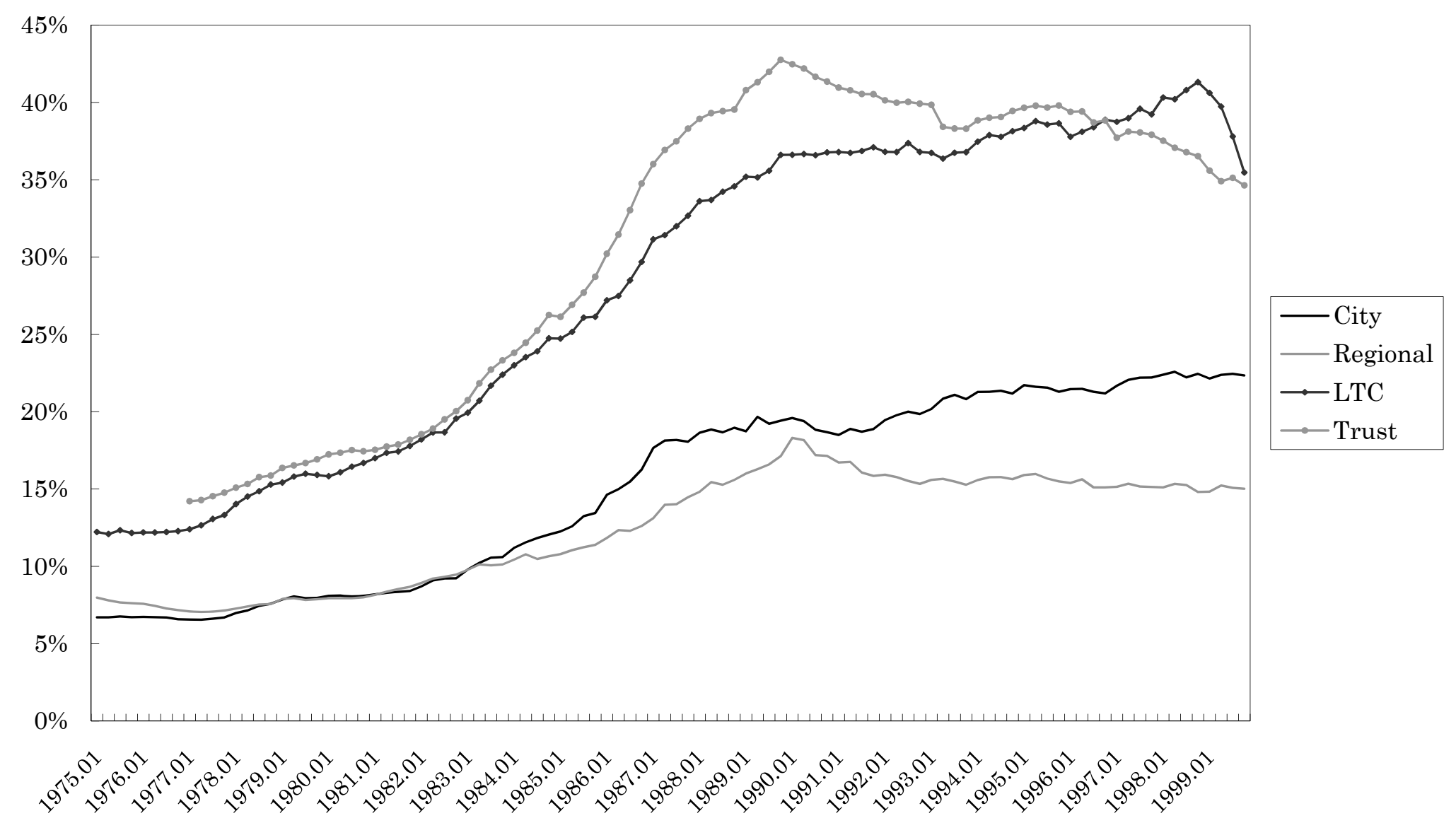

Source: Nikkei NEEDS Macroeconomic Data File. 
Figure 2 Loans Outstanding of Individual Industries by Japanese Banks

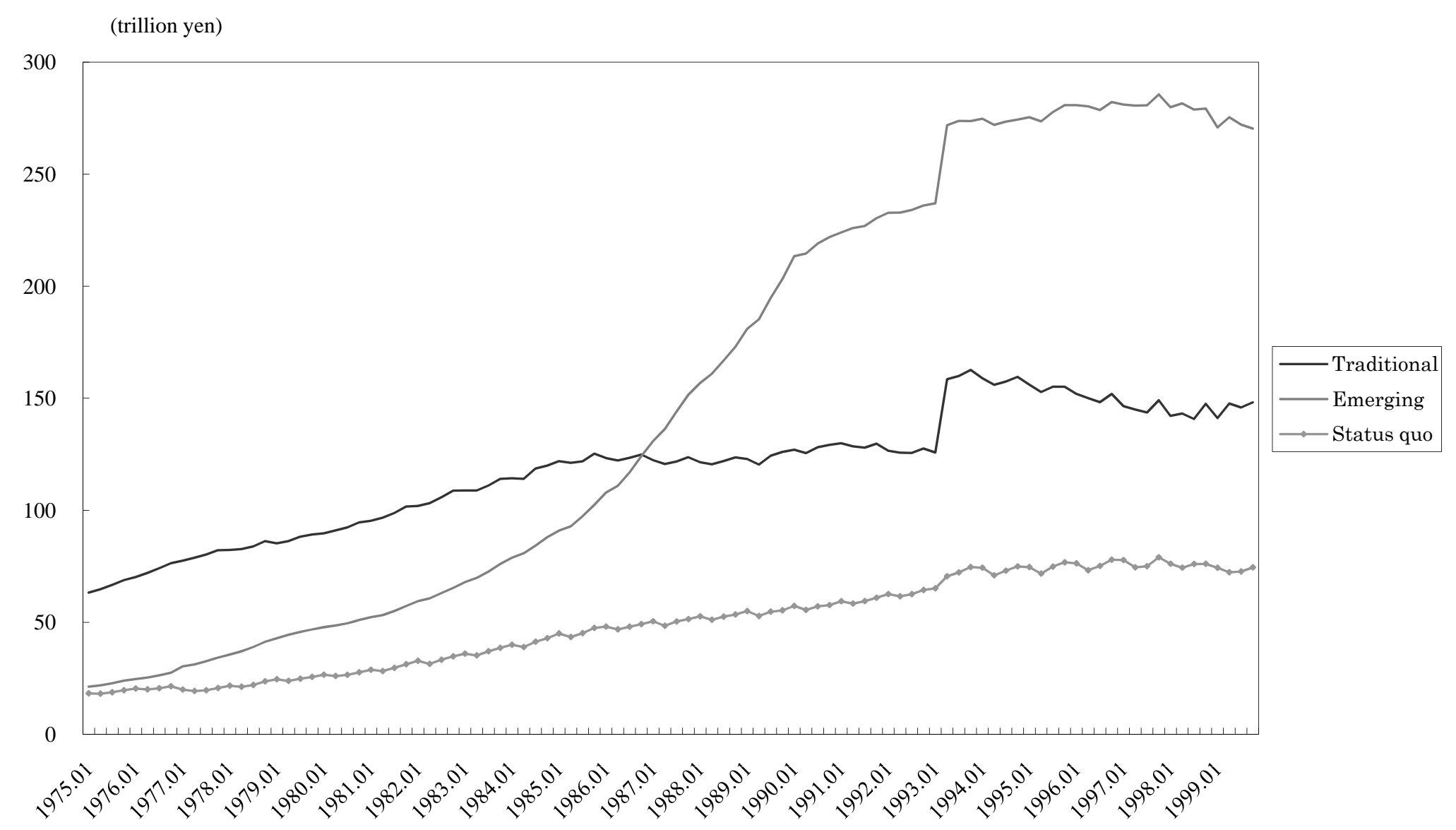


Figure 3 Loan Shares of Individual Industries by Japanese Banks

(a) Traditional industries

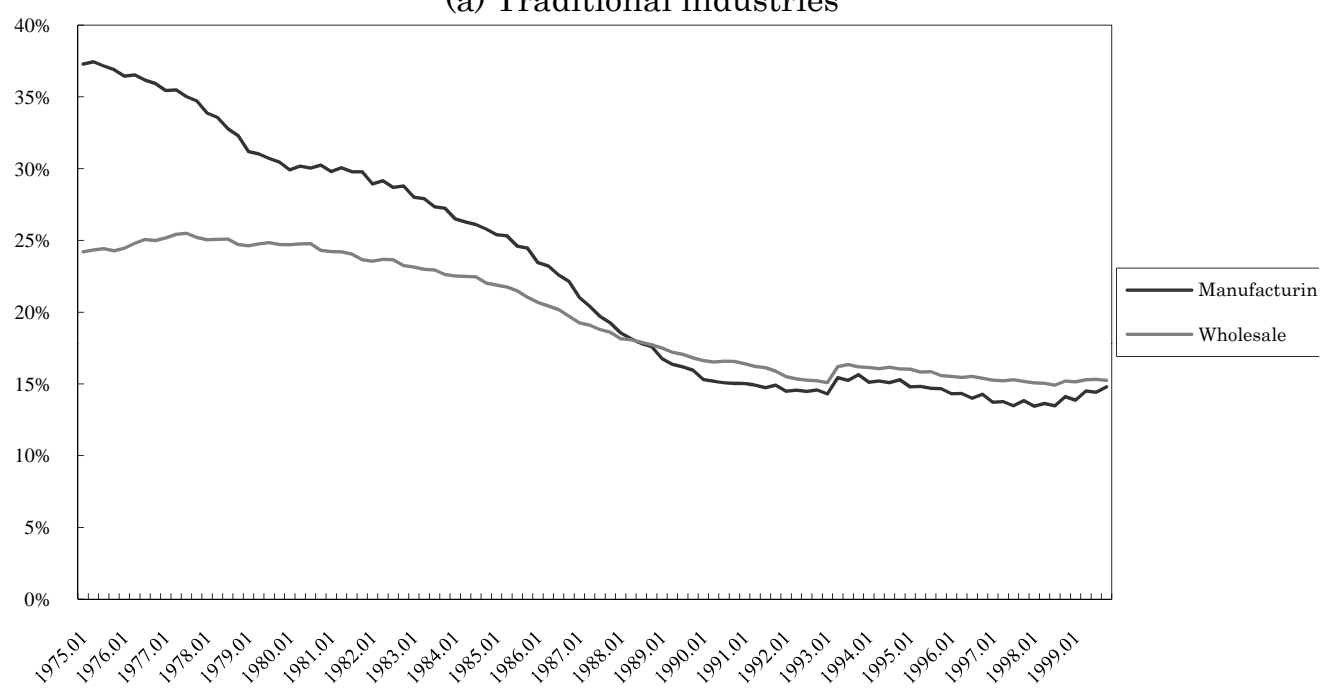

(b) Emerging industries

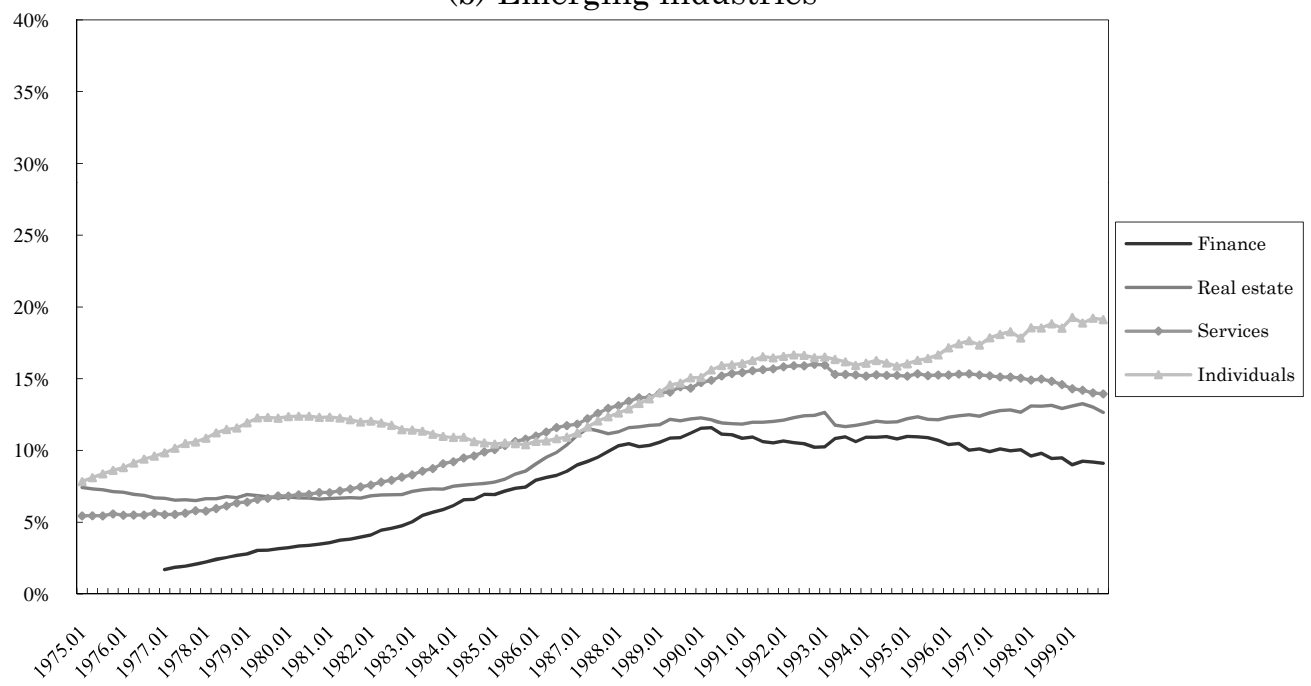

(c) Status quo industries

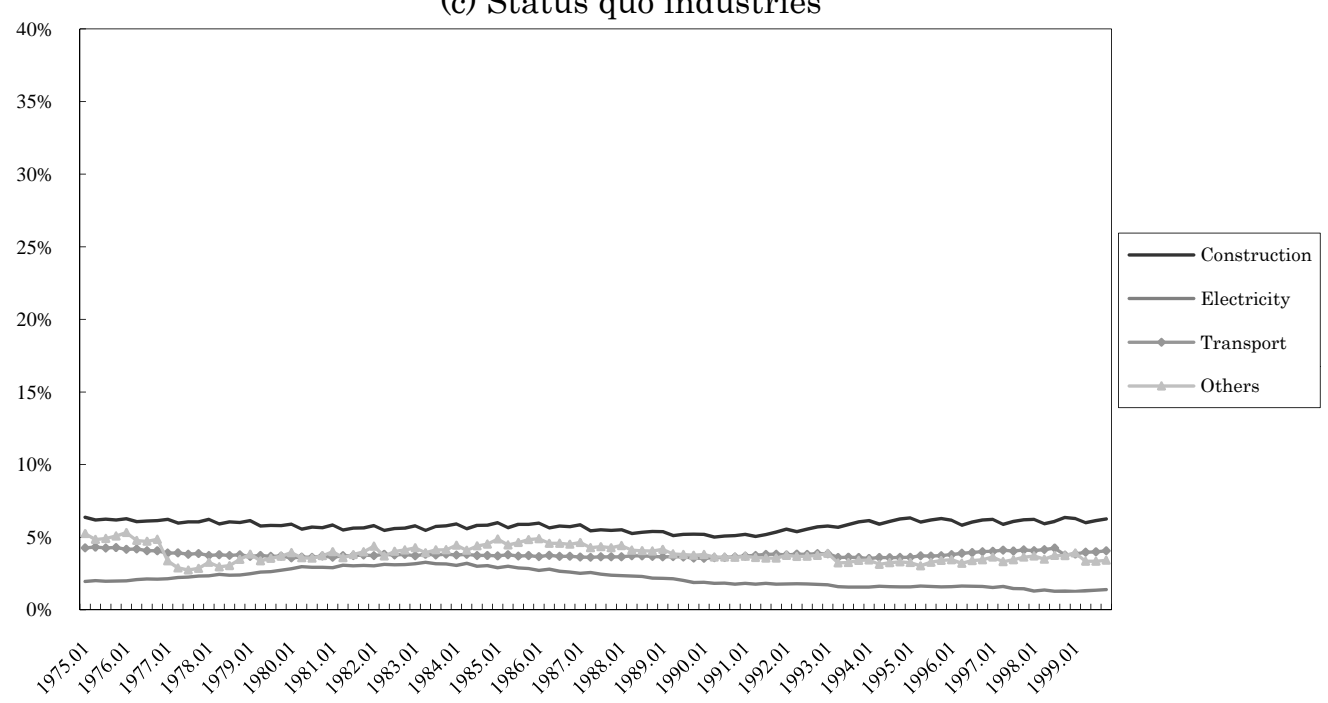

Source: Nikkei NEEDS Macroeconomic Data File.

Note: A jump in the second quarter of 1993 reflects changes in the definition of the data. The data of finance is incomplete because the data of trust banks is partly lacking. 

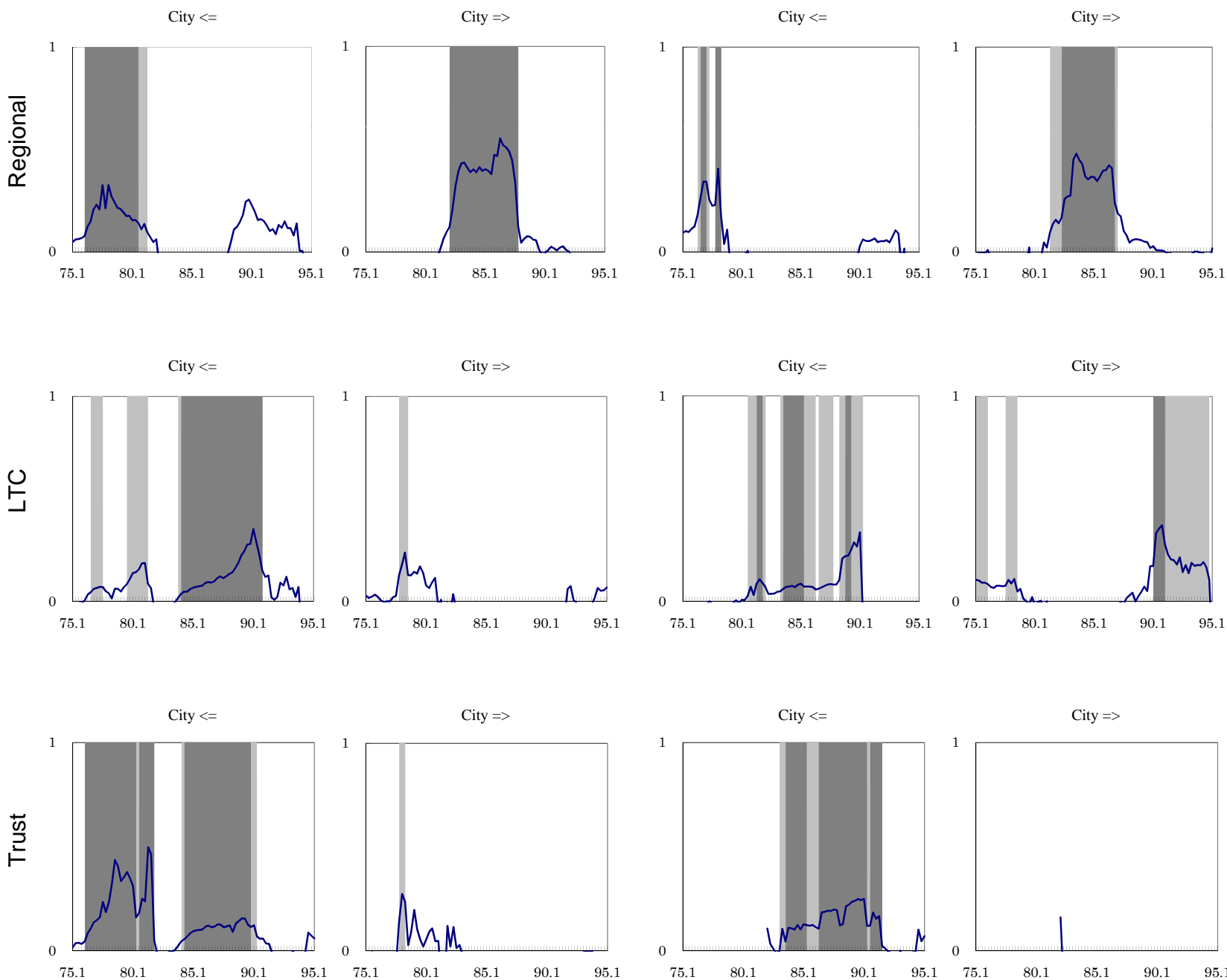

Note: This figure shows the results regarding sequential causality tests between loan ratios of city banks and those of the other types of banks in individual industry groups, without macroeconomic variables. The rows are the types of banks (except for city banks). The columns are the industry groups as borrowers. In each panel, " => City " represents a causality from the relevant type of banks to city banks. " City => " is the reverse causality. The horizontal axis is the median of each sumple period (e.g., the results at "1982:1" represent the results of the sample period "1977:1 -- 1986:4"). The data from 1970:1 to 1999:4 are used to obtain results for 1975:1 ("1970:1 -1979:4") through 1995:1 ("1990:1 -- 1999:4"). The solid line is an estimated sum of the coefficients of the loan ratio of the type of banks that is an explanatory variable in the VAR. The dark and light shadows represent that the sum of the coefficients is significant at $1 \%$ and $5 \%$ level in an F-test, respectively. The optimal lag of a VAR is determined based on SBIC. Note that results of trust banks are not obtained by 1981:4 because of lack of the data. 
Traditional

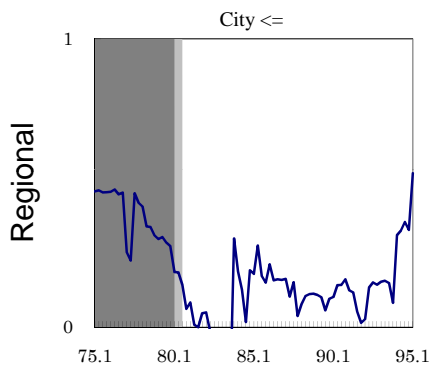

City $<=$

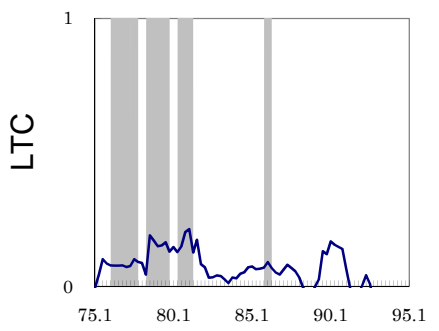

City $<=$

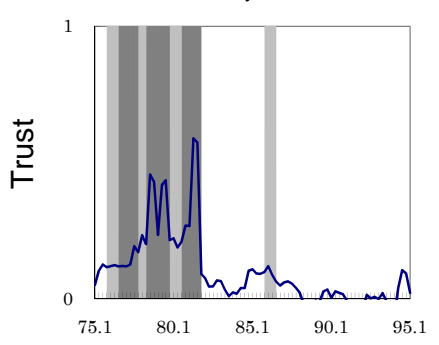

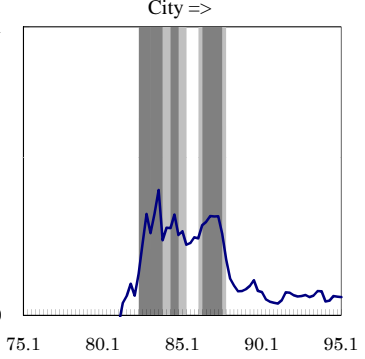

City $=>$

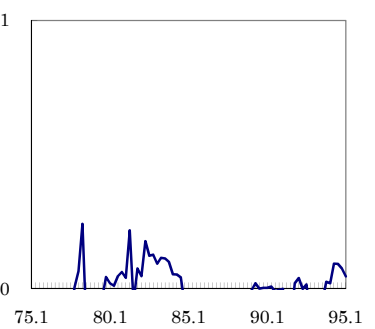

City $=>$

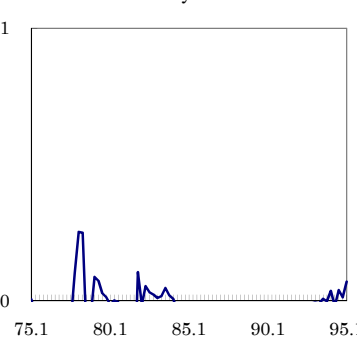

Emerging
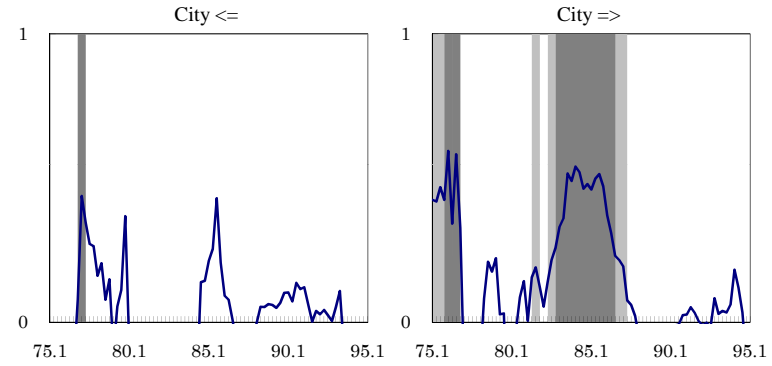

City $<=$
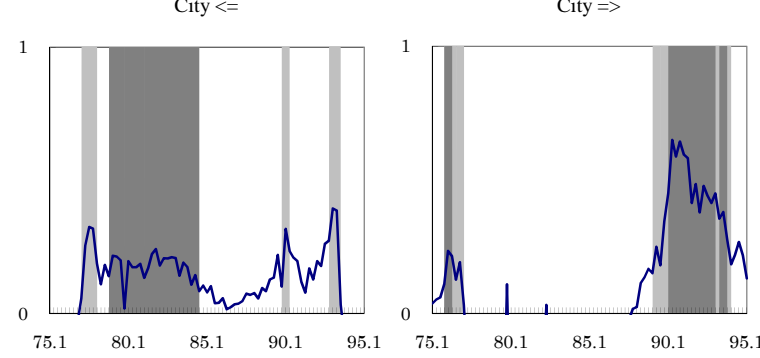

City $<=$
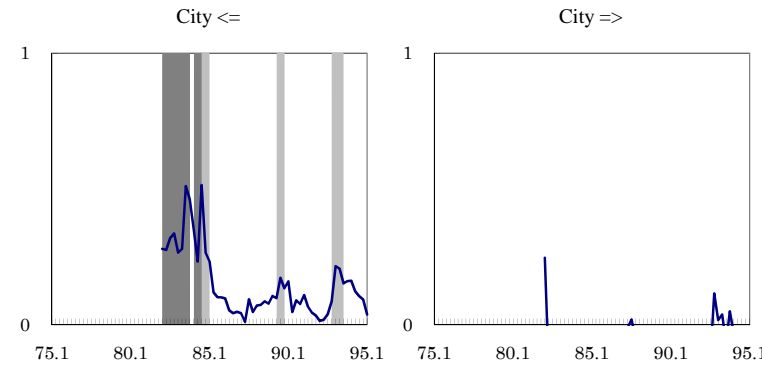

Note: This figure shows the results of sequential causality tests between loan ratios of city banks and those of the other types of banks in individual industry groups, with one and two lagged macro variables. The black line is an estimated sum of the coefficients of the loan ratio of the type of banks that is an explanatory variable in the VAR. Other detail is seen in Figure 2. 